\title{
EFIKASI DIRI MAHASISWA PENDIDIKAN BIOLOGI FKIP UNIVERSITAS RIAU DALAM PEMBELAJARAN DARING
}

\author{
Aisyah Rusy Anasti ${ }^{1 *}$, Wan Syafi' ${ }^{2}{ }^{2}$, L.N. Firdaus ${ }^{3)}$ \\ ${ }^{1 *}$ E-mail: rusyaisyah@gmail.com \\ ${ }^{2)}$ E-mail: wan.syafii@ lecturer.unri.ac.id \\ ${ }^{3)}$ E-mail: firdausln@lecturer.unri.ac.id \\ 1) 2) 3) Pendidikan Biologi, FKIP, Universitas Riau
}

\begin{abstract}
The purpose of this study was to determine the level of self-efficacy of Biology Education FKIP Riau University students in online learning. To achieve these objectives, this study used a descriptive research design with a quantitative approach and survey method (online). The sample in the study were all students of Biology Education FKIP University of Riau who actively participated in online lecture activities as many as 101 students. Data was obtained through the distribution of a random questionnaire (online) in the form of a google form, and interview guidelines conducted through the message feature on the Whatsapp. The results showed that the level of self-efficacy of Biology Education FKIP Riau University students in online learning was high. This is influenced by the high value of self-efficacy on the four dimensions, namely technology, time management, social interaction and learning. Thus, students' self-efficacy in relation to academic activities while online learning is applied is classified as good.
\end{abstract}

Keywords: Self-efficacy; online learning; biology education students

\begin{abstract}
ABSTRAK
Tujuan penelitian ini adalah untuk mengetahui tingkat efikasi diri mahasiswa Pendidikan Biologi FKIP Universitas Riau dalam pembelajaran daring. Untuk mencapai tujuan tersebut, penelitian ini menggunakan rancangan penelitian deskriptif dengan pendekatan kuantitatif dan metode survei (online). Sampel pada penelitian yaitu seluruh mahasiswa Pendidikan Biologi FKIP Universitas Riau yang aktif mengikuti kegiatan perkuliahan daring sebanyak 101 mahasiswa. Data diperoleh melalui penyebaran angket secara random (online) disemua angkatan aktif dalam bentuk google form, dan pedoman wawancara yang dilakukan melalui fitur pesan pada aplikasi Whatsapp. Analisis data melalui perhitungan nilai rata-rata. Hasil penelitian menunjukkan bahwa tingkat efikasi diri mahasiswa Pendidikan Biologi FKIP Universitas Riau dalam pembelajaran daring tergolong tinggi. Hal ini ditunjukkan karena tingginya nilai efikasi diri pada keempat dimensi, yakni teknologi, manajemen waktu, interaksi sosial, dan pembelajaran. Dengan demikian, kemampuan diri mahasiswa sehubungan dengan aktivitas akademik selama pembelajaran daring diterapkan tergolong baik.
\end{abstract}

Kata Kunci: Efikasi diri; pembelajaran daring; mahasiswa pendidikan biologi 


\section{PENDAHULUAN}

Efikasi diri merupakan persepsi individu tentang kemampuan yang dimilikinya untuk menyelesaikan suatu tugas (Bandura, 1997). Pada konsep capaian akademik, efikasi diri merupakan keyakinan individu mengenai kemampuannya dalam menyelesaikan atau menjalankan tugas akademik (Suryani et al., 2020). Semakin tinggi efikasi diri seorang individu, maka rasa keyakinan dan kepercayaan dirinya juga semakin tinggi, sehingga semakin kuat motivasi untuk menyelesaikan pekerjaannya (Bangung et al., 2020). Efikasi diri akademik sangat penting karena dapat mengontrol motivasi mencapai harapan-harapan akademik (Park dan Kim dalam Sari, 2020).

Masalah efikasi diri mahasiswa dalam kaitannya dengan pembelajaran dalam jaringan (daring) sejak pandemi Covid-19 semakin menarik perhatian dari sejumlah peneliti (Naji et al., 2020; Septiana, 2020; Suryani et al., 2020). Hal ini karena efikasi diri berperan penting pada keberhasilan proses pembelajaran daring (Ithriah et al., 2020). Efikasi diri dikaitkan pada peranannya sebagai faktor psikologis yang penting dalam lingkungan pembelajaran. Dapat dilihat bahwa efikasi diri akan mempengaruhi perilaku, performa akademik dan keberhasilan akademik (Fitriah et al., 2020; Yokoyama, 2019; Zimmerman \& Kulikowich, 2016).

Pada pembelajaran daring, motivasi menjadi faktor penting dalam proses belajar, dan aspek kunci dari motivasi adalah efikasi diri (Zimmerman \& Kulikowich, 2016). Efikasi diri akan mengkonstruksi perilaku positif dalam menyelesaikan tugas (Bandura, 1997). Perilaku seorang individu akan dipengaruhi oleh efikasi diri. Hal ini kemudian menentukan tindakan yang akan dilakukan ketika muncul hambatan atau kesulitan dalam mencapai target yang diinginkan. Individu yang memiliki efikasi diri yang tinggi memiliki kemungkinan untuk lebih berhasil dalam pembelajaran daring (Zimmerman \& Kulikowich, 2016). Menurut Yavuzalp \& Bahcivan (2020), efikasi diri menjadi faktor penting dalam pembelajaran daring terutama kepada mahasiswa yang baru pertama kali mengalami hal tersebut.

Pembelajaran daring di Program Studi Pendidikan Biologi FKIP Universitas Riau secara penuh diterapkan sejak pandemi Covid-19 pada bulan Maret 2020. Hal ini merupakan pertama kalinya pembelajaran daring secara penuh diberlakukan dalam kegiatan belajar di kampus. Teknis kegiatan pembelajaran daring yang berbeda dari sistem tatap muka, dalam pelaksanaannya tidak menutup kemungkinan terjadinya kendala. Permasalahan yang terjadi pada pembelajaran daring di Prodi Pendidikan Biologi, meliputi hal seperti motivasi belajar yang menurun, rasa jenuh, kekurangan referensi bahan ajar, kesulitan dalam memahami 
materi perkuliahan, hingga masalah komunikasi dalam pengerjaan tugas. Maulah et al (2020), persepsi mahasiswa Pendidikan Biologi terhadap perkuliahan daring menunjukkan efektivitas pembelajaran dirasa kurang puas karena bergantung pada kemampuan dan motivasi belajar. Muliadi et al (2021), pembelajaran daring di Pendidikan Biologi berlangsung kurang efektif, karena masalah miskomunikasi, lingkungan belajar yang tidak kondusif hingga penurunan motivasi belajar.

Peran efikasi diri dalam pembelajaran daring dapat dilihat pada perubahan perilaku mahasiswa (Zimmerman \& Kulikowich, 2016). Hal ini karena efikasi diri merupakan faktor penting yang berperan terhadap motivasi belajar. Kondisi perkuliahan daring di Program Studi Pendidikan Biologi menarik untuk dikaji. Hal ini guna mendapatkan gambaran perilaku dan kemampuan diri mahasiswa selama pembelajaran daring berlangsung. Pada proses pembelajaran di Program Studi Pendidikan Biologi, tidak hanya sebatas penyampaian materi teoritis, namun juga ada pelaksanaan kegiatan praktikum dan praktek mengajar. Diharapkan dari pembelajaran daring, mahasiswa dapat menyesuaikan diri dengan kondisi yang terjadi. Perolehan hasil belajar yang memuaskan akan tergantung dari diri mahasiswa itu sendiri. Bagaimana mahasiswa tersebut dapat menyesuaikan diri dengan situasi yang ada, sehingga mampu mengatur dirinya agar bersikap lebih aktif dalam proses pembelajaran.

Keberhasilan akademik dan performa akademik dipengaruhi oleh efikasi diri (Fitriah et al., 2020; Yokoyama, 2019). Menurut Schneider \& Preckel (2017), dari 105 indikator yang mempengaruhi performa akademik, efikasi diri menempati posisi kedua. Hal ini membuktikan bahwa tingkat efikasi diri yang tinggi dapat dikaitkan dengan naiknya performa akademik. Berbagai performa akademik yang dipengaruhi oleh efikasi diri antara lain, interaksi antar teman sebaya (Prior et al., 2016), prestasi akademik (Akturk \& Ozturk, 2019; Basith et al., 2020; Suraya \& Nordin, 2017), kemandirian belajar (Safraturrina et al., 2016; Valentin \& Hadi, 2018), hasil belajar (Firdaningsih, 2016; Ningsih \& Hayati, 2020; Safitri et al., 2019), motivasi belajar (Aryanti \& Muhsin, 2020), dan motivasi berprestasi (Prihatini et al., 2018; Yuliatika et al., 2017).

Hubungan efikasi diri dalam pembelajaran daring dibahas dengan cara yang berbedabeda pada berbagai literatur berdasarkan perspektif, konteks, maupun bidang studi. Alqurashi (2016), mengatakan mayoritas studi efikasi diri terfokus pada dimensi teknologi, yakni efikasi diri dalam penggunaan komputer (Nardi \& Ranieri, 2019; Yildiz, 2018), internet dan pencarian informasi (Azis et al., 2019), serta manajemen lingkungan pembelajaran (Arpaci, 2017; di Marco et al., 2019). Penelitian kali ini untuk menguji hasil 
penelitian sebelumnya yang dilakukan Zimmerman dan Kulikowich, dengan subyek dan lokasi penelitian yang berbeda. Perbedaannya pada penelitian ini subyeknya adalah mahasiswa Pendidikan Biologi FKIP Universitas Riau.

Selama pembelajaran daring diterapkan, belum ada penelitian yang membahas mengenai efikasi diri mahasiswa Program Studi Pendidikan Biologi FKIP Universitas Riau. Penelitian ini perlu dilakukan agar mahasiswa dapat mengetahui kemampuan dan keyakinannya dalam aktivitas akademik, kemudian dosen atau Program Studi Pendidikan Biologi dapat mengetahui tingkat efikasi diri mahasiswanya selama proses pembelajaran daring. Berdasarkan hal tersebut, program studi dapat mengambil kesempatan untuk meningkatkan efikasi diri mahasiswanya, dan dapat digunakan sebagai informasi untuk mengidentifikasi area yang menjadi kelemahan mahasiswa. Selain itu, untuk menggambarkan proses pembelajaran daring di tengah pandemi Covid-19, serta dapat dijadikan informasi dasar untuk meningkatkan kualitas dari pembelajaran daring. Penelitian ini bertujuan untuk mengetahui tingkat efikasi diri mahasiswa Pendidikan Biologi FKIP Universitas Riau dalam pembelajaran daring.

\section{METODE PENELITIAN}

Penelitian ini menggunakan rancangan penelitian deskriptif dengan pendekatan kuantitatif dan metode survei (online). Populasi penelitian ini adalah seluruh mahasiswa Pendidikan Biologi FKIP Universitas Riau angkatan 2016-2020 yang aktif mengikuti perkuliahan daring sebanyak 331 mahasiswa. Jumlah sampel ditetapkan menggunakan teknik random sampling, dan diperoleh sebesar 30,5\% jumlah populasi atau sebanyak 101 mahasiswa.

Tabel 1. Jumlah sampel mahasiswa aktif pendidikan biologi berdasarkan jenjang tahun kuliah

\begin{tabular}{|c|c|c|}
\hline Angkatan & Tahun ke & Jumlah \\
\hline 2020 & 1 & 25 \\
\hline 2019 & 2 & 26 \\
\hline 2018 & 3 & 19 \\
\hline 2017 & 4 & 17 \\
\hline 2016 & 5 & 14 \\
\hline \multicolumn{2}{|c|}{ Total } & 101 \\
\hline
\end{tabular}

Data dalam penelitian ini diperoleh melalui angket dan pedoman wawancara. Angket terdiri atas 40 butir pernyataan positif dan negatif. Terdapat 4 dimensi efikasi diri dalam pembelajaran daring yang diteliti, yaitu teknologi, manajemen waktu, interaksi sosial, dan 
pembelajaran. Pedoman wawancara berjenis wawancara terbuka dengan 20 butir pertanyaan. Penyebaran angket dilakukan secara random (online) dalam bentuk google form. Wawancara dilakukan dengan mengajukan pertanyaan kepada responden melalui fitur pesan pada aplikasi Whatsapp.

Data hasil penelitian yang telah didapat kemudian dihitung, diklasifikasikan, dan dianalisis secara deskriptif. Untuk menghitung nilai dari angket efikasi diri, peneliti menggunakan rumus Mean (Sugiyono, 2012):

$$
M=\frac{\sum x}{N}
$$

dimana: $\mathbf{M}=$ Rata-rata skor, $\sum \mathbf{x}=$ Jumlah seluruh skor, $\mathbf{N}=$ Jumlah komponen angket respon

Setelah data diperoleh, data kemudian dikonversikan ke dalam suatu tabel interval (Tabel 2). Data selanjutnya akan diklasifikasi serta dianalisis secara deskriptif untuk lebih mengetahui tingkat efikasi diri yang dimiliki mahasiswa Pendidikan Biologi FKIP Universitas Riau.

Tabel 2. Interval dan kategori efikasi diri dalam pembelajaran daring

\begin{tabular}{llll}
\hline Kriteria & Interval & Kategori \\
\hline $\mathrm{x} \geq \mathrm{M}+\mathrm{SD}$ & $\mathrm{x} \geq 2,33$ & Tinggi & \\
\hline $\mathrm{M}-\mathrm{SD} \leq \mathrm{x}<\mathrm{M}+\mathrm{SD}$ & $1,67 \leq \mathrm{x}<2,33$ & Sedang & \\
\hline $\mathrm{x}<\mathrm{M}-\mathrm{SD}$ & $\mathrm{x}<1,67$ & Rendah & \\
\hline & & & (Adian, 2018)
\end{tabular}

dimana: $\mathbf{x}=$ Jumlah rata-rata skor nilai tes, $\mathbf{M}($ Mean $)=1 / 2$ (skor tertinggi + skor terendah), SD $($ Standar Deviasi $)=1 / 6($ skor tertinggi - skor terendah $)$

\section{HASIL DAN PEMBAHASAN}

Efikasi Diri Mahasiswa Pendidikan Biologi FKIP Universitas Riau dalam pembelajaran daring secara keseluruhan tergolong tinggi, dengan total nilai rerata sebesar 2,634. Didukung dari hasil penelitian yang menunjukkan tingkat efikasi diri yang tinggi pada Dimensi Teknologi, Manajemen Waktu, Interaksi Sosial serta Pembelajaran. Dengan demikian, kemampuan mahasiswa sehubungan dengan aktivitas akademik selama pembelajaran daring diterapkan tergolong baik.

Tabel 3. Profil efikasi diri mahasiswa pendidikan biologi dalam pembelajaran daring

\begin{tabular}{lcl}
\hline Dimensi Efikasi Diri & Rerata & Kategori \\
\hline Teknologi & 2,611 & Tinggi \\
Manajemen Waktu & 2,518 & Tinggi \\
Interaksi Sosial & 2,759 & Tinggi \\
Pembelajaran & 2,646 & Tinggi \\
\hline Rerata & $\mathbf{2 , 6 3 4}$ & Tinggi \\
\hline
\end{tabular}

Keterangan: $\mathrm{n}=101$ Responden 
Nilai rerata efikasi diri dalam pembelajaran daring pada dimensi teknologi tergolong tinggi. Artinya, dalam penggunaan perangkat dan teknologi informasi pada proses pembelajaran daring mahasiswa Pendidikan Biologi FKIP Universitas Riau berada pada kategori tinggi. Hal tersebut disebabkan faktor kemampuan literasi digital. Artinya, mahasiswa Pendidikan Biologi memiliki pengetahuan teknologi yang baik. Hal ini akan mendukung setiap individu ketika mengikuti kegiatan pembelajaran daring. Prior et al (2016), literasi digital memiliki hubungan yang positif terhadap efikasi diri dalam pembelajaran daring. Kemampuan literasi digital merupakan salah satu yang mendukung interaksi teknologi yang efektif dalam berbagai situasi pembelajaran sepanjang hayat (Kenton \& Blummer, 2010). Menurut Tang \& Chaw (2016), setiap individu harus memiliki literasi digital untuk bisa belajar secara efektif mengikuti pembelajaran secara daring. Syah et al (2019), kebutuhan informasi mempengaruhi intensitas penggunaan media digital sebagai literasi. Kemampuan literasi digital yang tinggi akan mendukung persepsi mahasiswa untuk percaya diri dalam penggunaan teknologi.

Nilai rerata efikasi diri dalam pembelajaran daring pada dimensi manajemen waktu tergolong tinggi. Artinya, bahwa Mahasiswa Pendidikan Biologi FKIP Universitas Riau dalam hal monitoring dan mengalokasikan waktu belajarnya selama kegiatan perkuliahan daring berada pada kategori tinggi. Hal tersebut disebabkan faktor kemandirian individu yang tinggi, sehingga menunjukkan bahwa mahasiswa Pendidikan Biologi sudah dapat menyusun dan mengelola waktu belajarnya secara efektif. Karena kemandirian individu akan berpengaruh terhadap pengambilan keputusan yang tepat dalam pengelolaan waktu (Guner, 2021). Memiliki keyakinan diri yang tinggi berperan penting dalam pengaturan jadwal individu (Nasrullah \& Khan, 2015). Mahasiswa dapat mengatur waktu belajarnya dengan baik terlepas dari berbagai kesibukan dalam perkuliahan. Hal ini dapat dilihat dari kemampuan mahasiswa mengalokasikan waktunya dengan efisien.

Nilai rerata efikasi diri dalam pembelajaran daring pada dimensi interaksi sosial tergolong tinggi. Artinya, interaksi dengan dosen dan teman sebaya pada mahasiswa Pendidikan Biologi FKIP Universitas Riau dalam pembelajaran daring berada pada kategori tinggi. Hal tersebut dipengaruhi oleh faktor kemampuan komunikasi mahasiswa. Hal ini tidak terlepas dari kebiasaan responden dalam menggunakan perangkat teknologi sebagai alat komunikasi, sehingga responden terbiasa dan berani menyampaikan serta mendengar gagasan orang lain melalui media digital. Artinya, mahasiswa merasa lebih nyaman dalam mengemukakan gagasan dan pertanyaan dalam pembelajaran daring. Karena pembelajaran 
daring menekankan pada kemampuan interaksi sosial melalui perangkat teknologi (Jaradat \& Ajlouni, 2020). Didukung oleh penelitian Perwita (2021), dengan kemampuan literasi media yang tinggi maka analisa terhadap informasi juga baik, sehingga individu mampu berpartisipasi secara aktif dalam kegiatan pembelajaran.

Nilai rerata efikasi diri dalam pembelajaran daring pada dimensi pembelajaran tergolong tinggi. Artinya, bahwa pemilihan dan penerapan strategi belajar pada mahasiswa Pendidikan Biologi FKIP Universitas Riau dalam pembelajaran daring dalam kategori tinggi. Hal tersebut disebabkan oleh faktor kemampuan mengatur diri dalam belajar (self regulated learning). Kemampuan regulasi diri yang baik akan membantu mahasiswa dalam menentukan tujuan belajar, menerapkan strategi belajar yang tepat, hingga menentukan hasil belajar yang diharapkan. Dengan demikian, diharapkan mahasiswa mampu melakukan evaluasi diri dari proses pembelajaran yang telah dilakukan. Efikasi diri dan regulasi diri yang tinggi, akan membuat mahasiswa mampu mengelola pengalaman belajarnya, sehingga dapat mencapai hasil belajar yang optimal (Jagad \& Khoirunnisa, 2018; Daryanes \& Fauza, 2020) Terdapat hubungan positif yang signifikan antara efikasi diri dan kemampuan regulasi diri indvidu dalam belajar (Efendi et al., 2020; Rochmatika et al., 2021). Dapat dikatakan bahwa kemampuan efikasi diri mampu memprediksi kemampuan self regulated learning (Yudha \& Nugroho, 2019) dan menurut Daryanes (2020) mahasiswa memiliki persepsi yang baik terhadap peningkatan kemampuan self regulation melalui penerapan strategi perkuliahan yang tepat yang dilaksanakan oleh dosen sehingga aspek efikasi diri dan self regulation juga dapat dilatihkan melalui penerapan strategi perkuliahan yang bermakna. Hal tersebut didukung oleh pendapat (Putra \& Daryanes, 2021) bahwa pendidik menghasilkan gagasan, perasaan, dan tindakan untuk mencapai tujuannya. Secara metakognitif, guru merencanakan, mengorganisasikan atau mengatur, menginstruksikan diri, memonitor dan melakukan evaluasi dalam aktivitas belajar.

\section{KESIMPULAN}

Berdasarkan pembahasan atas hasil, maka dapat disimpulkan bahwa tingkat efikasi diri mahasiswa Pendidikan Biologi FKIP Universitas Riau dalam pembelajaran daring tergolong tinggi. Hal ini ditandai dengan tingginya nilai efikasi diri pada dimensi teknologi, manajemen waktu, interaksi sosial, dan pembelajaran. Bagi peneliti selanjutnya diharapkan dapat berpedoman pada perkembangan instrumen terbaru dari efikasi diri dalam pembelajaran daring. Selain itu, juga dapat menggunakan responden program studi lain 
sehingga dapat menjadi bahan perbandingan penelitian. Karena penelitian yang dilakukan saat ini hanya terbatas pada mahasiswa Program Studi Pendidikan Biologi FKIP Universitas Riau.

\section{DAFTAR PUSTAKA}

Adian, K. (2018). Hubungan Antara Efikasi Diri dengan Tingkat Stress pada Mahasiswa Perantau Tahun Pertama di Yogyakarta. Universitas Sanata Dharma.

Akturk, A. O., \& Ozturk, H. S. (2019). Teacher's TPACK Levels and Students Self-Efficacy as Predictors of Students Academic Achievement. International Journal of Research in Education and Sciece, 5(1), 283-294.

Alqurashi, E. (2016). Self-Efficacy in Online Learning Environments: A Literature Review. Contemporary Issues in Education Research , 9(1), 45-52.

Arpaci, I. (2017). The Role of Self-Efficacy in Predicting Use of Distance Education Tools and Learning Management Systems. Turkish Online Journal of Distance Education, $18(1), 52-62$.

Aryanti, Y. D., \& Muhsin. (2020). Pengaruh Efikasi Diri, Perhatian Orang Tua, Iklim Kelas, dan Kreativitas Mengajar terhadap Motivasi Belajar Siswa. Economic Education Analysis Journal , 9(1), 243-260.

Azis, Y. M., Suharyati, H., \& Susanti, S. (2019). Relationship Between Prior Knowledge and Internet Self-Efficacy on the Success of Learning Mathematics by Using ELearning. Advances in Social Science, Education and Humanities Research , 440, 4347.

Bandura, A. (1997). Self-Efficacy: The Exercise of Control. W.H. Freeman Company.

Bangung, P., Hariani, L. S., \& Walipah. (2020). Motivasi Berprestasi: Konsep Diri, Kecerdasan Emosional, dan Efikasi Diri. Jurnal Riset Pendidikan Ekonomi , 5(1), 2431.

Basith, A., Syahputra, A., \& Ichwanto, M. A. (2020). Academic Self-Efficacy as Predictor of Academic Achievement. Jurnal Pendidikan Indonesia, 9(1), 163-170.

Daryanes, F. (2020). Persepsi Mahasiswa Terhadap Strategi Perkuliahan "Students As Researchers" Dalam Melatih Kemampuan Self Regulation Mahasiswa. Bioilmi: Jurnal Pendidikan, 6(2), 103-111. https://doi.org/10.19109/bioilmi.v6i2.6962 
Daryanes, F., \& Fauza, N. (2020). Peningkatan Self Regulation Mahasiswa melalui Strategi Perkuliahan "Students as Researchers" berbasis Online Learning. Bioedusiana, 5(2), 131-144. https://doi.org/https://doi.org/10.37058/bioed.v5i2.2246

di Marco, L., el Kechai, H., Martin, D. K., \& Gillois, P. (2019). Blended Learning for

French Health Students: Does Acceptance of a Learning Management System Influence Students Self-Efficacy? MEDINFO, 1169-1173.

Efendi, D. H., Sandayati, V., \& Hutasuhut, A. F. (2020). Hubungan Efekasi Diri dengan Regulasi Diri dalam Belajar pada Mahasiswa Fakultas Kedokteran Universitas Malahayati. Anfusina: Journal of Psychology, 3(1), 21-32.

Firdaningsih. (2016). Efikasi Diri dan Motivasi Berprestasi dalam Meningkatkan Hasil Belajar Sejarah. Jurnal Penelitian Dan Penilaian Pendidikan , 1(1), 47-60.

Fitriah, L. A., Wijayadi, A. W., \& Hayati, N. (2020). Efikasi Diri, Kestabilan Emosi, dan Keberhasilan Akademik Mahasiswa dalam Perkuliahan. Jurnal Riset Pedagogik, 4(1), 44-51.

Guner, U. C. (2021). The Relationship Between Time, Management, Self-Efficacy and Academic Success Levels of Nursing and Midwifery Students and Various Variables. Journal of Samsun Health Sciences , 6(1), 128-135.

Ithriah, S. A., Ridwandono, D., \& Suryanto, T. L. M. (2020). Online Learning Self-Efficacy: The Role in E-Learning Success. Journal of Physics: Conference Series , 1569, 1-6.

Jagad, H. K. M., \& Khoirunnisa, R. N. (2018). Hubungan antara Efikasi Diri dengan Self Regulated Learning pada Siswa SMPN X. Jurnal Penelitian Psikologi , 5(3), 1-6.

Jaradat, S. A., \& Ajlouni, A. O. (2020). Social Presence and Self-Efficacy in Relation to Students Satisfication in Online Learning Setting: A Predictive Study. International Journal of Education and Practice, 8(4), 759-778.

Kenton, J., \& Blummer, B. (2010). Promoting digital literacy skills: examples form the literature and implications for academic librarians. Community and Junior Collage Libraries, 16(2), 84-99.

Maulah, S., Nurul, F., \& Ummah, N. R. (2020). Persepsi Mahasiswa Biologi terhadap Perkuliahan Daring sebagai Sarana Pembelajaran Selama Pandemi Covid-19. Alveoli: Jurnal Pendidikan Biologi , 1(2), 49-61.

Muliadi, A., Mirawati, B., \& Jannah, H. (2021). Efektivitas Pembelajaran Daring di Masa Pandemi Covid-19: Persepsi Mahasiswa Pendidikan Biologi. Jurnal Ilmu Sosial Dan Pendidikan , 5(2), 625-633. 
Naji, K. K., Du, X., Tarlochan, F., Ebead, U., Hasan, M. A., \& Al-Ali, A. K. (2020). Engineering Students Readiness to Transition to Emergency Online Learning in Response to Covid-19: Case of Qatar. EURASIA Journal of Mathematics, Science and Technology Education, 16(10), 1-17.

Nardi, A., \& Ranieri, M. (2019). Comparing paper-based and electronic multiple-choices examinations with personal devices: impacts on students performance, self-efficacy, and satisfication. British Journal of Educational Technology, 50(3), 1495-1506.

Nasrullah, S., \& Khan, M. S. (2015). The Impact of Time Management on the Students Academic Achievements. Journal of Literature, Language and Liguistics , 11(1), 6671.

Ningsih, W. F., \& Hayati, I. R. (2020). Dampak Efikasi Diri terhadap Proses dan Hasil Belajar Matematika. Journal on Teacher Education , 1(2), 26-32.

Perwita, D. (2021). Literasi media digital mahasiswa universitas jendral soedirman. Jurnal Ilmiah Ekonomi Dan Pembelajarannya, 9(1), 8-13.

Prihatini, A., Romas, M. Z., \& Wdiantoro, Fx. W. (2018). Hubungan antara Efikasi Diri dengan Motivasi Berprestasi pada Mahasiswa Universitas X Yogyakarta. Jurnal Psikologi, 14(1), 7-11.

Prior, D. D., Mazanov, J., Meacheam, D., Heaslip, G., \& Hanson, J. (2016). Attitude, Digital Literacy, and Self-Efficacy: Flow-on effects for online learning behavior. Internet and Higher Education , 29(2016), 91-97.

Putra, R. A., \& Daryanes, F. (2021). ANALISIS SELF REGULATION GURU BIOLOGI SMA NEGERI KOTA PEKANBARU. Prosiding Seminar Nasional Pendidikan IPA, $1,1-6$.

Rochmatika, A., Eva, N., \& Tantiani, F. F. (2021). Pengaruh Self-Efficacy terhadap SelfRegulated Learning pada Santriwati. Psyche: Jurnal Psikologi Universitas Muhammadiyah Lampung, 3(2), 134-144.

Safitri, I., Yolida, B., \& Surbakti, A. (2019). Hubungan Self-Efficacy Berdasarkan Gender dengan Hasil Belajar Siswa Mata Pelajaran IPA. Jurnal Bioterdidik , 7(3), 32-40.

Safraturrina, Nurdin, S., \& Martunis. (2016). Hubungan Efikasi Diri dengan Kemandirian Belajar pada Siswa (Suatu Studi Penelitian pada MAN Darussalam). Jurnal Ilmiah Mahasiswa Bimbingan Dan Konseling, 1(2), 66-72.

Sari, T. T. (2020). Self-Efficacy dan Dukungan Keluarga dalam Keberhasilan Belajar dari Rumah Di Masa Pandemi Covid-19. Journal Education Research and Development, 
$4(2), 127-136$.

Schneider, M., \& Preckel, F. (2017). Variables Associated With Achievement in Higher Education: A Systematic Review of Meta Analyses. Psychologycal Bulletin.

Septiana, Y. (2020). Survei Efikasi Diri Mahasiswa Prodi Pendidikan Akutansi pada Masa Pembelajaran Jarak Jauh. Jurnal Ekonomi Pendidikan , 17(2), 83-97.

Sugiyono. (2012). Statistika untuk Penelitian. Alfabeta.

Suraya, W. H., \& Nordin, J. (2017). Self-Efficacy and Academic Performance of Secondary

School Students in Perak: An Exploratory Outlook. International Journal of Academic Research in Progressive Education and Development , 6(3), 41-55.

Suryani, L., Seto, S. B., \& Bantas, M. G. D. (2020). Hubungan Efikasi Diri dan Motivasi Belajar Terhadap Hasil Belajar Berbasis E-Learning pada Mahasiswa Program Studi Pendidikan Matematika Universitas Flores. Jurnal Kependidikan , 6(2), 275-283.

Syah, R., Darmawan, D., \& Purnawan, A. (2019). Analisis Faktor yang Mempengaruhi Kemampuan Literasi Digital. Jurnal AKRAB , 10(2), 60-70.

Tang, C. M., \& Chaw, L. Y. (2016). Digital Literacy: A Prerequisite for Effective Learning in a Blended Learning Environment? The Electronic Journal of E-Learning , 14(1), 54 65.

Valentin, R. R., \& Hadi, N. U. (2018). Analisis Keyakinan Diri (Self-Efficacy) Akademik dan Pola Asuh Orangtua terhadap Kemandirian Belajar Siswa Mata Pelajaran Ekonomi Kelas X SMA Negeri 1 Tulungagung Tahun Pelajaran 2017/2018. Jurnal Pendidikan Ekonomi , 12(1), 142-154.

Yavuzalp, N., \& Bahcivan, E. (2020). The Online Learning Self-Efficacy Scale: Its Adaptation Into Turkish And Interpretation According to Various Variables. Turkish Online Journal of Distance Education, 21(1), 31-44.

Yildiz, D. H. (2018). Flipped learning readiness in teaching programming in middle schools: modelling its relation to various variables. Journal of Computer Assisted Learning , 34(6), 939-959.

Yokoyama, S. (2019). Academic Self-Efficacy and Academic Performance in Online Learning: A Mini Review. Frontiers in Psychology , 9, 1-4.

Yudha, A., \& Nugroho, F. (2019). Self Regulated Learning Ditinjau dari Efikasi Diri Siswa. Jurnal Psikologi Jambi , 4(1), 25-29.

Yuliatika, D., Rahmawati, S. W., \& Palupi, S. R. (2017). Self-Efficacy dan Motivasi Beprestasi Siswa SMA Negeri 7 Purworejo. Jurnal Psiko Utama, 5(2), 51-59. 
Jurnal Biogenesis Vol. 18 (1): 42-53, 2022

(C) Program Studi Pendidikan Biologi FKIP Universitas Riau e-ISSN : 2776-1924

Zimmerman, W. A., \& Kulikowich, J. M. (2016). Online Learning Self-Efficacy in Students With and Without Online Learning Experience. The American Journal of Distance Education, 30(3), 180-191. 